\title{
High cytotoxicity and anti-proliferative activity of algae extracts on an in vitro model of human hepatocellular carcinoma
}

\author{
Celso Alves', Susete Pinteus, André Horta and Rui Pedrosa
}

*Correspondence: celso.
alves@ipleiria.pt
MARE - Marine
and Environmental
Sciences Centre, ESTM,
Polytechnic Institute of Leiria,
2520-641 Peniche, Portugal

\begin{abstract}
Background: Cancer represents a serious threat for human health with high social and economic impacts worldwide. Therefore, the development of new anticancer drugs is of most importance. The aim of the present study was to evaluate the antitumor potential of twelve algae from Portugal coast on an in vitro model of human hepatocellular carcinoma (HepG-2 cells).

Results: Both extracts of Asparagopsis armata $(1000 \mu \mathrm{g} / \mathrm{ml} ; 24 \mathrm{~h})$ presented high cytotoxicity with $11.22 \pm 2.98$ and $1.51 \pm 0.38 \%$ of HepG-2 live cells, respectively. Sphaerococcus coronopifolius methanolic and dichloromethane extracts $(1000 \mu \mathrm{g} / \mathrm{ml})$ also generated high reduction on HepG-2 viability $(14.04 \pm 2.62$ and $12.84 \pm 3.82 \%$ of HepG-2 live cells, respectively). The most potent anti-proliferative activity was induced by dichloromethane extract $(1000 \mu \mathrm{g} / \mathrm{ml} ; 24 \mathrm{~h})$ of Sphaerococcus coronopifolius, Asparagopsis armata and Plocamium cartilagineum with $99.61 \pm 0.27,98.56 \pm 0.81$ and $85.13 \pm 1.04 \%$ of cell's proliferation reduction, respectively. Sphaerococcus coronopifolius dichloromethane extract exhibited the highest potency both on cytotoxicity and anti-proliferation assays with an $\mathrm{IC}_{50}$ of 14.1 and $32.3 \mu \mathrm{g} / \mathrm{ml}$, respectively.
\end{abstract}

Conclusions: Sphaerococcus coronopifolius is a promising source of new molecules with possible application on cancer therapeutics.

Keywords: Bioactive compounds, Marine natural products, HepG-2 cells, Seaweeds, Antitumor activity, Cancer

\section{Background}

Nowadays, the malignant tumours are one of the major cause of death in humans and have high impact in industrialized countries (Fukahori et al. 2008; Smyrniotopoulos et al. 2010). In the last decades, the search and development of new drugs have increased, and nature became a relevant resource for the discovery of anticancer compounds. Today, more than $60 \%$ of the commercially available anticancer drugs are of naturally origin. Naturally derived anti-proliferative drugs such as doxorubicin, bleomycin, daunomicin, vincristine, mytomicin $\mathrm{C}$ and vinblastine play an important role in curative cancer chemotherapy in a number of solid tumours and haematological malignancies (Jimeno et al. 2004; Sithranga Boopathy and Kathiresan 2010). 
Marine organisms have already proved to be a rich source of bioactive compounds, and as a result, their exploration for pharmacological purposes have increased greatly along last years. Marine organisms survive and live within complex communities and also in close association with other organisms, consequently, they produce bioactive molecules normally as secondary metabolites in response to ecological pressures such as competition for space, maintenance of unfouled surfaces, deterrence of predation and the ability to successfully reproduce (Chin et al. 2006; Li et al. 2013; Salvador et al. 2007; Shanmughapriya et al. 2008). These compounds have evolved over millions of years as defence strategies against predators, to keep competitors at bay or to paralyze their prey (Haefner 2003). The marine environment represents a vast proportion of the earth's biodiversity and it has been estimate that biological diversity in marine ecosystems may be higher than in tropical rain forests (Allsopp et al. 2009). This offers an abundance of highly potent secondary metabolites for exploitation as bioactive compounds. Moreover, it is widely accepted that marine natural products provide unusual and unique chemical structures upon which molecular modelling and chemical synthesis of new drugs can be based with greater efficacy and specificity for the treatment of many human diseases (Ebada et al. 2010; Jha and Zi-rong 2004; Stonik 2009). To date, many unique chemically compounds of marine origin with various biological activities have been isolated, and some of them are under investigation and are being used to develop new pharmaceuticals (Kijjoa and Sawangwong 2004). Among the marine organisms, algae have arisen as an emerging interest in the biomedical area and recent trends in macro-algae natural drug research are revealing the biomedical potential of these organisms in human diseases treatment. They are producers of bioactive substances, which show different biological activities, such as antioxidant, antimicrobial, antiviral, anthelmintic, anti-inflammatory, anticoagulant, antituberculosis, antiviral and antitumor (Chew et al. 2008; Mayer et al. 2009; Murray et al. 2013; Pinteus et al. 2015; Ye et al. 2008). Moreover, numerous algae and their metabolites have shown potent cytotoxic activities and various authors have suggested the consumption of algae as a chemopreventive measure against several cancers (Taskin et al. 2010; Yuan and Walsh 2006). Different groups of bioactive molecules with antitumor activity have been isolated from algae, such as sulfated polysaccharides, phenolic compounds, carotenoids and terpenoids. Such compounds have showed anti-proliferative activity in human cancer cell lines in vitro, as well as inhibitive activity in tumours growing in animal models (Kuo et al. 2011; Kwon et al. 2007; Lins et al. 2009; Thoppil and Bishayee 2011; Zandi et al. 2010). Therefore the aim of this study was to evaluate the antitumor potential of twelve algae from Peniche coast (Portugal) on an in vitro carcinoma model of human hepatocellular cancer (HepG-2 cells).

\section{Methods}

\section{Sampling and identification of algae extracts}

Algae were collected along the Peniche coast (Portugal), during June and July (2011), and immediately transported to the laboratory. They were cleaned and washed with sea water and then in fresh water to remove epiphytes, detritus and encrusting material. Algae were identified as Asparagopsis armata, Ceramium ciliatum, Plocamium cartilagineum and Sphaerococcus coronopifolius (Rhodophyta division); Fucus spiralis, Halopteris filicina, Saccorhiza polyschides and Stypocaulon scoparium (Heterokontophyta division); Codium adhaerens, Codium tomentosum, Codium vermilara and Ulva 
compressa (Chlorophyta division). Identification was performed by Dr. Susete Pinteus, supported by Marine Algae: Biodiversity, Taxonomy, Environmental Assessment, and Biotechnology guide (Pereira and Neto 2014). Finally algae were kept at $-80^{\circ} \mathrm{C}$ (Thermo, Electron Corporation) until extraction process.

\section{Preparation of algae extracts}

Algae were previously frozen at $-80{ }^{\circ} \mathrm{C}$ and then ground with a mixer grinder to make a powder. Each alga sample was sequentially extracted in 1:4 biomass:solvent ratio with methanol (>99 \%, Fisher Scientific, United Kingdom) and dichloromethane (Fisher Scientific, United Kingdom) solvents at constant stirring for $12 \mathrm{~h}$. Liquid-liquid extraction was also performed for the methanolic extract, using $n$-Hexane (Lab-Scan analytical Sciences, Poland). The solvents were evaporated in a rotary evaporator (Laborota 4000, Heidolph) at $40{ }^{\circ} \mathrm{C}$ and the extracts were then solubilized in dimethyl sulfoxide (Sigma, Germany) and stored at $-20^{\circ} \mathrm{C}$ until further use.

\section{Maintenance of cell culture}

Human hepatocellular cancer model (HepG-2 cells) (ATCC HB-8065) was acquired from American Type Culture Collection (ATCC). HepG-2 cells were cultured in RPMI medium (Sigma, USA) supplemented with $10 \%$ of fetal bovine serum (FBS) (Gibco, USA) and $1 \%$ of antimycotic $(100 \mathrm{U} / \mathrm{ml}$ penicillin G, $0.25 \mu \mathrm{g} / \mathrm{ml}$ amphotericin B and $100 \mu \mathrm{g} / \mathrm{ml}$ streptomycin) (Sigma, USA). Cell medium was changed every 3 days, and the cells reached confluence after 5-6 days of initial seeding. For subculture, cells were dissociated with tripsin-EDTA (Sigma, USA), split 1:3 and subculture in Petri dishes with $25 \mathrm{~cm}^{2}$ growth area. Cells were maintained in $95 \%$ of humidified atmosphere, $5 \%$ of $\mathrm{CO}_{2}$ and $37^{\circ} \mathrm{C}$ of temperature.

\section{In vitro evaluation of cytotoxic and anti-proliferative activities}

Algae activities were evaluated by decreases on cell viability and cell proliferation studies induced by methanolic and dichloromethane extracts. Cell viability studies were performed after cells reached the total confluence in 96-well plates. The algae extracts were dissolved in culture medium without FBS and sterile filtered $(0.2 \mu \mathrm{m})$. Then, the extracts $(1000 \mu \mathrm{g} / \mathrm{ml})$ were incubated with cells during $24 \mathrm{~h}$. For algae extracts with high effect after $24 \mathrm{~h}$ of incubation, the time-course effect was also evaluated after $12 \mathrm{~h}$ of incubation. For cellular proliferation studies, cells were seeded in 96-well plates and after $36 \mathrm{~h}$ of initial seeding, they were incubated during $24 \mathrm{~h}$ with algae extracts $(1000 \mu \mathrm{g} / \mathrm{ml})$, previously dissolved in cultured medium with FBS and sterile filtered $(0.2 \mu \mathrm{m}$, Whatman, UK). The extracts which produced the most potent effects after $24 \mathrm{~h}$ incubation, the time-course effect was also evaluated (12 and $48 \mathrm{~h}$ ).

Dose-response assays (10-1000 $\mu \mathrm{g} / \mathrm{ml} ; 24 \mathrm{~h})$ were accessed for the extracts that exhibited the highest effects, both on the cytotoxicity and anti-proliferation assays. Cisplatin (Sigma, USA) and tamoxifen (Sigma, China) were used as standard drugs.

\section{HepG-2 cells viability and proliferation: 3-[4,5-dimethylthiazol-2-yl]-2,5-diphenyl tetrazolium bromide (MTT) colorimetric method}

The antitumor capacity of algae extracts on cell viability and cell proliferation studies were measured using MTT method. This assay is based on cleavage of the tetrazolium 
salt MTT by mitochondrial dehydrogenases of viable cells to form a blue formazan product. The formazan produced is proportional to the number of living cells present and can be measured colorimetrically (Yuan and Walsh 2006). After the treatment with the methanol and dichloromethane extracts, the cells medium was removed and cells were washed with Hanks' medium (medium composition in mM: $\mathrm{NaCl} \mathrm{137,} \mathrm{KCl} 5, \mathrm{MgSO} 4$ 0.8, Na2HPO4 0.33, KH2PO4 0.44, $\mathrm{CaCl} 20.25$; $\mathrm{MgCl} 2$ 1.0, Tris $\mathrm{HCl} 0.15$ and sodium butyrate 1.0, pH 7.4). After that, cells were incubated with MTT (1.2 mM) (Sigma, Germany), previously dissolved in Hanks' medium, during $4 \mathrm{~h}$ at $37^{\circ} \mathrm{C}$. The formazan products were dissolved in isopropanol (Panreac, Spain) with $0.04 \mathrm{~N} \mathrm{HCl}$ and the absorbance (Abs) was read at $570 \mathrm{~nm}$ (Biotec, Synergy H1 hybrid reader).

\section{HepG-2 cells viability and proliferation: calcein-AM fluorescent method}

The calcein-AM method is a fluorescent method which evaluates the cell esterases activity in order to estimate the cell viability and proliferation. The cell membranes are permeable to calcein-AM, a non-fluorescent dye, which is taken up and converted by intracellular esterases to calcein. The calcein remains trapped within the cell emitting green fluorescence that can measured (Pedrosa and Soares-da-Silva 2002).

In order to confirm the results obtained before, extracts that exhibit high activity in the MTT assay were also tested by calcein-AM method. After treatment with algae extracts, cells were washed twice times with Hanks' medium and loaded with $2 \mu \mathrm{M}$ of calceinAM (Invitrogen, USA), previously dissolved in Hanks' medium, at room temperature for $30 \mathrm{~min}$. The natural fluorescence of the cells was determined on wells incubated with Hanks medium without calcein-AM. Fluorescence (F) was measured at $485 \mathrm{~nm}$ excitation and $530 \mathrm{~nm}$ emission wavelengths in a multiplate reader (Biotec, Synergy H1 hybrid reader).

The results obtained for both studies were expressed in percentage of control:

$$
(\% \text { of control })=(\text { Abs or F sample } / \text { Abs or F control }) \times 100 \text {. }
$$

\section{Statistical analysis}

One-way analysis of variance (ANOVA) was used followed by Dunnett test to discriminate significant differences between extracts and controls or vehicle. These analyzes were performed using GraphPad InStat for Windows. Results are presented as mean \pm standard error of mean (SEM). The significance level was inferred at $\mathrm{p}<0.05$ or $\mathrm{p}<0.01$ for all statistical tests. The $\mathrm{IC}_{50}$ concentration was calculated from nonlinear regression analysis using the GraphPad Prism software with the equation: $\mathrm{Y}=100 /\left[1+10^{\left(\mathrm{X}-\operatorname{LogIC} C_{50}\right)}\right]$.

\section{Results}

\section{Cytotoxicity activities of algae extracts: HepG-2 cell viability}

The methanolic and dichloromethane extracts obtained from twelve algae were tested for their ability to induce cytotoxicity on HepG-2 cells $(1000 \mu \mathrm{g} / \mathrm{ml}$; $24 \mathrm{~h})$ (Fig. 1). In the methanolic extract the major potential was exhibited by algae that belong to Rhodophyta and Heterokontophyta division. The methanolic extracts of red algae Asparagopsis armata (11.22 $\pm 2.98 \%$ of HepG-2 live cells) and Sphaerococcus coronopifolius $(14.04 \pm 2.62 \%$ of HepG-2 live cells) showed high cytotoxicity on HepG-2 cells, inducing a cell viability decrease in more than 80 \% (Fig. 1a). As regards to dichloromethane 

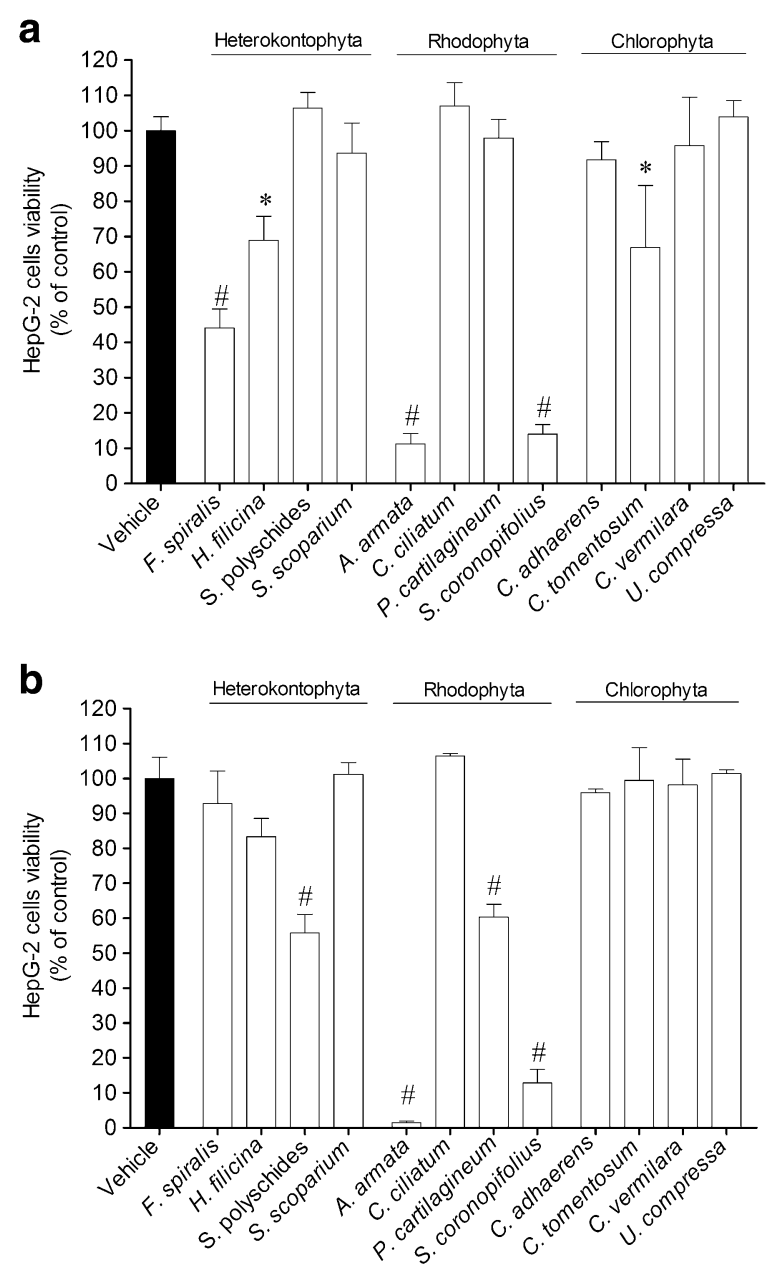

Fig. 1 The effects on HepG-2 cells viability (\% of control) induced by methanolic (a) and dichloromethane (b) extracts $(1000 \mu \mathrm{g} / \mathrm{ml})$ after $24 \mathrm{~h}$ of incubation-MTT method. Each column represents the mean of 8 experiments per group; vertical lines show SEM. ${ }^{*} p<0.01$ and ${ }^{*} p<0.05$ compared with control

extracts, the highest activity was achieved by $A$. armata and S. coronopifolius extracts which exhibited capacity to reduce cell viability in more than 80 \% (Fig. 1b). Algae belonging to Chlorophyta division did not showed significant cytotoxicity activity on HepG-2 cells (Fig. 1).

The extracts that showed capacity to reduce cell's viability in more than $50 \%$ were also tested through the calcein-AM fluorescent method. Regarding to the methanolic extract, A. armata presented similar results to those obtained in the MTT method, however S. coronopifolius and $F$. spiralis presented much less activity in the reduction of cell viability. On the other hand, the dichloromethane extracts showed similar activity in the reduction of the cell viability in both methods; however S. coronopifolius presented an even more marked effect in the calcein-AM method (Fig. 2). Dose-response assays were accessed in order to define the potency of the effects. As it is shown on Table 1, the dichloromethane extract of $S$. coronopifolius exhibited the lowest $\mathrm{IC}_{50}(14.1 \mu \mathrm{g} / \mathrm{ml})$. For the standard drugs, only cisplatin exhibited cytotoxicity on HepG-2 cell $\left(\mathrm{IC}_{50}: 136.5 \mu \mathrm{g} /\right.$ $\mathrm{ml}$ ) (Table 1). The time-course effect was also evaluated for the extracts that displayed 


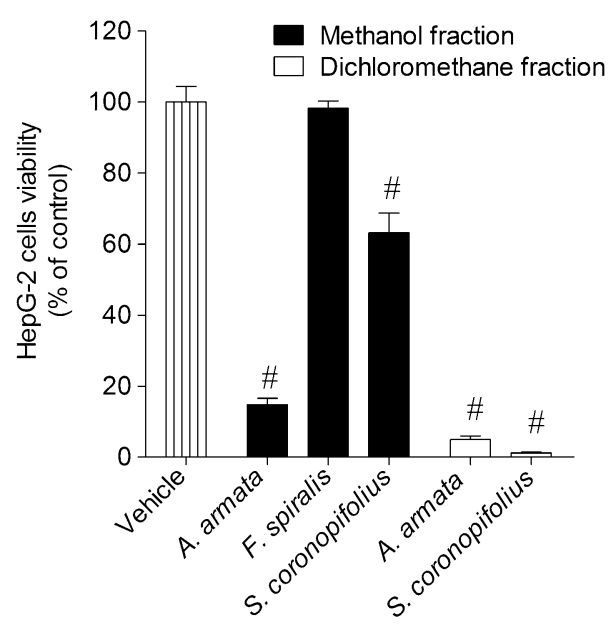

Fig. 2 The effects on HepG-2 cells viability (\% of control) induced by methanolic and dichloromethane extracts $(1000 \mathrm{\mu g} / \mathrm{ml})$ after $24 \mathrm{~h}$ of incubation-calcein-AM method. Each column represents the mean of 8 experiments per group; vertical lines show SEM. ${ }^{\#} \mathrm{p}<0.01$ compared with control

Table $1 \quad I_{50}$ values obtained for methanolic and dichloromethane extracts ( $\mu \mathrm{g}$ extract/ml) that presented the highest cytotoxicity activity on HepG-2 cells

\begin{tabular}{lll}
\hline Algae & Extract & \\
\cline { 2 - 3 } & $\begin{array}{l}\text { Methanol } \\
\mathbf{I C}_{\mathbf{5 0}}(\boldsymbol{\mu} \mathbf{g} / \mathbf{m l})\end{array}$ & $\begin{array}{l}\text { Dichloromethane } \\
\mathbf{I C}_{\mathbf{5 0}}(\boldsymbol{\mu g} / \mathbf{m l})\end{array}$ \\
\hline Fucus spiralis & $739.4(521.9-1047.0)$ & - \\
Asparagopsis armata & $567.9(317.7-1015.0)$ & $473.1(341.9-654.7)$ \\
Sphaerococcus coronopifolius & $470.6(310.7-712.6)$ & $14.1(8.1-24.6)$ \\
\hline
\end{tabular}

Values are expressed as means with $95 \%$ confidence intervals. Cisplatin and tamoxifen were used as standard drugs. Cisplatin exhibited an $\mathrm{IC}_{50}$ of $136.5 \mu \mathrm{g} / \mathrm{ml}(116.8-159.5)$ and tamoxifen did not showed cytotoxicity

the highest decrease $(1000 \mu \mathrm{g} / \mathrm{ml} ; 24 \mathrm{~h})$ on the HepG-2 cells viability. In this assay cells were incubated during 12 and $24 \mathrm{~h}$ with extracts at $1000 \mu \mathrm{g} / \mathrm{ml}$. For both extracts, a timedependent effect was observed. However, during the first $12 \mathrm{~h}$ of incubation, the effect induced by $S$. coronopifolius and $A$. armata methanol extracts were more marked when compared with the F. spiralis methanolic extract-induced HepG-2 cell death (Fig. 3).

\section{Anti-proliferative activity of algae extracts: HepG-2 cells proliferation}

To test the effect of the methanol and dichloromethane extracts on HepG-2 cells proliferation, cells were incubated with extracts during $24 \mathrm{~h}$ at $1000 \mu \mathrm{g} / \mathrm{ml}$. As shown in Fig. 4a, the methanolic extracts of algae belonging to Chlorophyta group did not show any activity on HepG-2 cells proliferation. On the other hand, F. spiralis (44.60 $\pm 6.75 \%$ of HepG-2 cell proliferation), S. polyschides (62.66 $\pm 2.95 \%$ of HepG-2 cell proliferation), A. armata (43.42 $\pm 7.69 \%$ of HepG-2 cell proliferation) and S. coronopifolius $(44.87 \pm 3.64 \%$ of HepG-2 cell proliferation) showed the highest inhibitory effects on the cell proliferation. However, the highest inhibition was induced by dichloromethane extract of $A$. armata ( $1.44 \pm 0.81 \%$ of HepG-2 cell proliferation), P. cartilagineum $(14.87 \pm 1.04 \%$ of HepG-2 cell proliferation) and S. coronopifolius $(0.39 \pm 0.27 \%$ of 

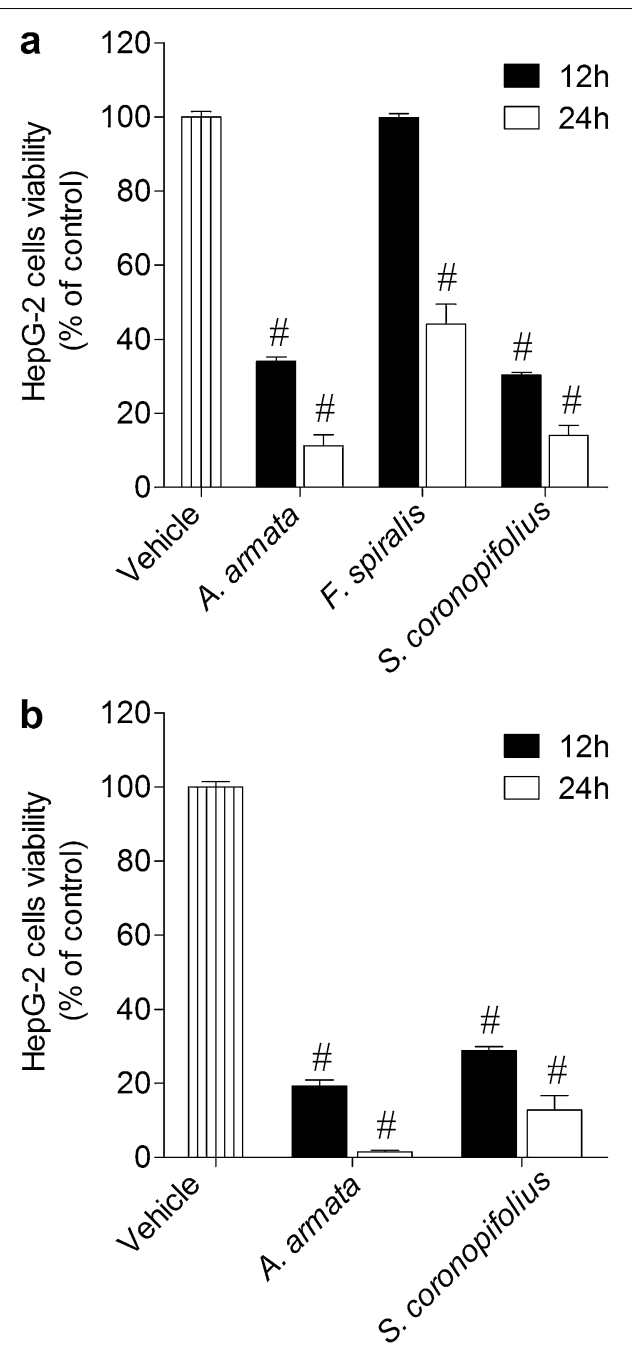

Fig. 3 The effects on HepG-2 cells viability (\% of control) induced by methanolic (a) and dichloromethane (b) extracts $(1000 \mathrm{\mu g} / \mathrm{ml})$ after 12 and $24 \mathrm{~h}$ of incubation-MTT method. Each column represents the mean of 8 experiments per group; vertical lines show SEM. ${ }^{*} \mathrm{p}<0.01$ compared with control

HepG-2 cell proliferation), that inhibited the cellular proliferation of HepG-2 cells in more than $80 \%(1000 \mu \mathrm{g} / \mathrm{ml}$; $24 \mathrm{~h})$ (Fig. 4b).

The extracts that revealed capacity to inhibit the HepG-2 cell's proliferation in more than $50 \%$ were also tested through the fluorescent method as in cell viability study. As demonstrated in Fig. 5, all the selected extracts had inhibitory effect on HepG-cellular proliferation as it was previously verified by the MTT method. The potency of the effects was evaluated by testing different concentrations of extract $(10-1000 \mu \mathrm{g} / \mathrm{ml})$ on HepG-2 cells proliferation with an incubation period of $24 \mathrm{~h}$. The lowest $\mathrm{IC}_{50}$ was exhibited by the dichloromethane extract of S. coronopifolius $(32.3 \mu \mathrm{g} / \mathrm{ml})$. For the standard drugs, the $\mathrm{IC}_{50}$ exhibited by cisplatin and tamoxifen was $22.63 \mu \mathrm{g} / \mathrm{ml}$ and $16.97 \mu \mathrm{g} / \mathrm{ml}$, respectively (Table 2).

The time-course effect was evaluated by testing the algae extracts $(1000 \mu \mathrm{g} / \mathrm{ml})$ on HepG-2 cells proliferation at 12, 24 and $48 \mathrm{~h}$ (Fig. 6). In both extracts, all algae extracts 

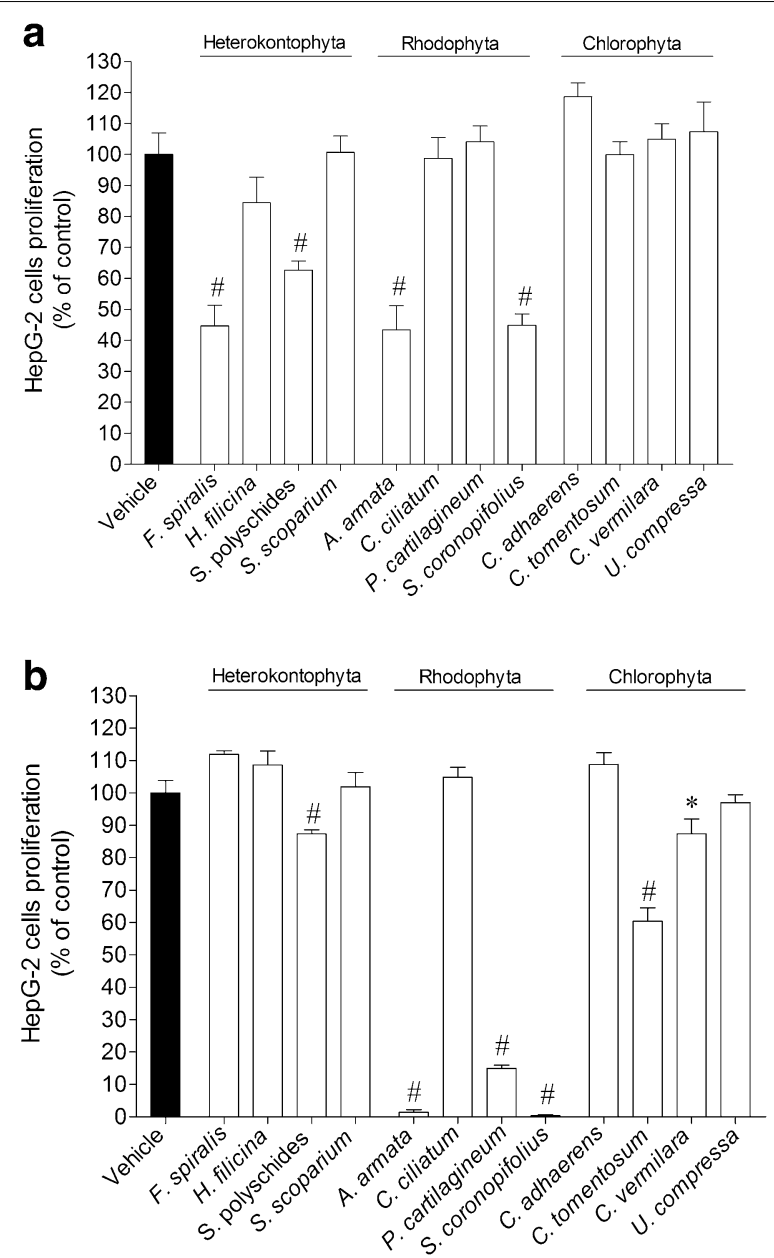

Fig. 4 The effects on HepG-2 cells proliferation (\% of control) induced by methanolic (a) and dichloromethane $(\mathbf{b})$ extracts $(1000 \mu \mathrm{g} / \mathrm{ml})$ after $24 \mathrm{~h}$ of incubation-MTT method. Each column represents the mean of 8 experiments per group; vertical lines show SEM. ${ }^{\#} p<0.01$ and ${ }^{*} p<0.05$ compared with control

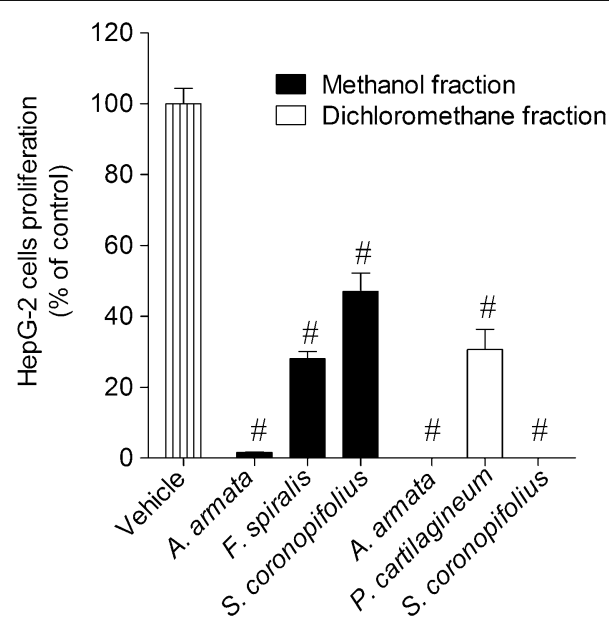

Fig. 5 Effects on HepG-2 cells proliferation (\% of control) induced by methanolic and dichloromethane extracts $(1000 \mu \mathrm{g} / \mathrm{ml})$ after $24 \mathrm{~h}$ of incubation - calcein-AM method. Each column represents the mean of 8 experiments per group; vertical lines show SEM. ${ }^{\#} p<0.01$ compared with control 
Table 2 IC $_{50}$ values obtained for methanolic and dichloromethane extracts ( $\mu \mathrm{g}$ extract/ml) that presented the highest anti-proliferative activity on HepG-2 cells

\begin{tabular}{|c|c|c|}
\hline \multirow[t]{2}{*}{ Algae } & \multicolumn{2}{|l|}{ Extract } \\
\hline & $\begin{array}{l}\text { Methanol } \\
\mathrm{IC}_{50}(\mu \mathrm{g} / \mathrm{ml})\end{array}$ & $\begin{array}{l}\text { Dichloromethane } \\
\mathrm{IC}_{50}(\mu \mathrm{g} / \mathrm{ml})\end{array}$ \\
\hline Fucus spiralis & $1039.0(603.7-1789.0)$ & - \\
\hline Asparagopsis armata & $857.3(524.5-1401.0)$ & $518.9(341.3-789.0)$ \\
\hline Plocamium cartilagineum & - & $852.7(471.9-1541.0)$ \\
\hline Sphaerococcus coronopifolius & $646.5(398.4-1049.0)$ & $32.3(22.4-46.7)$ \\
\hline
\end{tabular}

Values are expressed as means with $95 \%$ confidence intervals. Cisplatin and tamoxifen were used as standard drugs. Cisplatin and tamoxifen exhibited an $\mathrm{IC}_{50}$ of $22.63 \mu \mathrm{g} / \mathrm{ml}$ (18.24-28.07) and $16.97 \mu \mathrm{g} / \mathrm{ml}(11.83-24.35)$, respectively
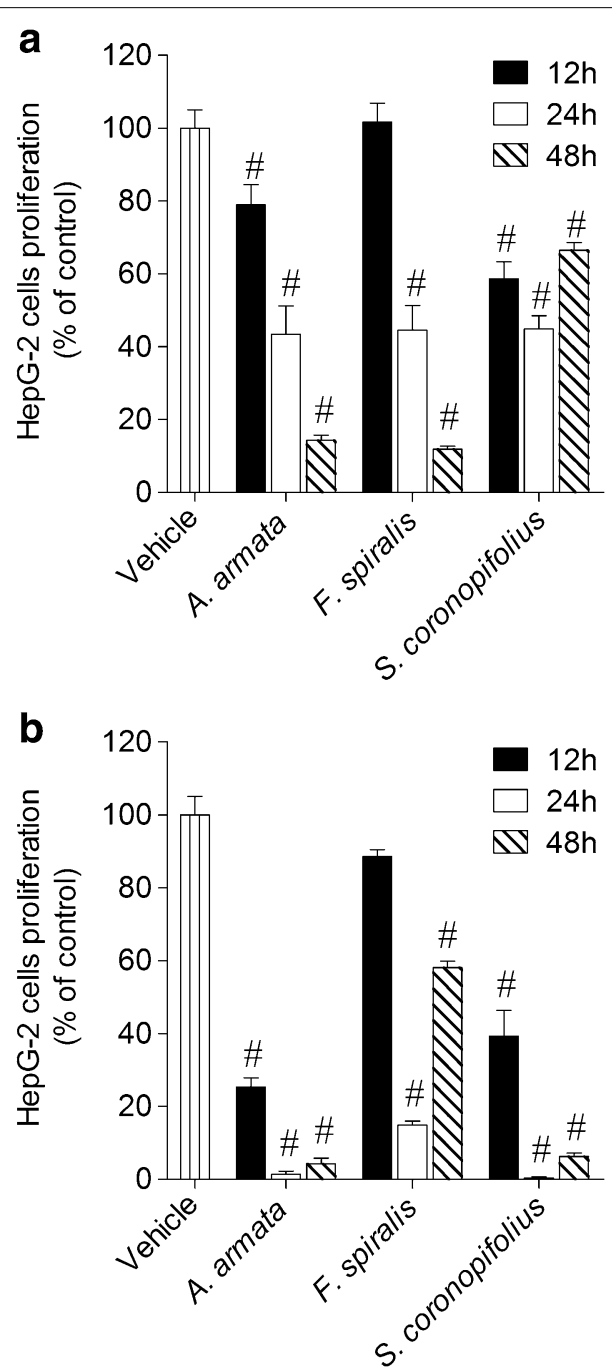

Fig. 6 Effects on HepG-2 cells proliferation (\% of control) induced by methanolic (a) and dichloromethane (b) extracts $(1000 \mu \mathrm{g} / \mathrm{ml})$ after 12, 24 and $48 \mathrm{~h}$ of incubation-MTT method. Each column represents the mean of 8 experiments per group; vertical lines show SEM. $p<0.01$ compared with control 
showed a time dependent effect between 12 and $24 \mathrm{~h}$. However, only the methanolic extracts of $A$. armata and $F$. spiralis exhibited a time dependent inhibition of cell proliferation after $48 \mathrm{~h}$ of incubation.

\section{Discussion}

Algae have caused an emerging interest in the biomedical area, mainly due to their content of biodynamic compounds with therapeutic value. These compounds are providing valuable ideas for the development of new drugs against different diseases (Ayesha et al. 2010; Ye et al. 2008). In this study, the antitumor potential of different algae from Peniche coast was evaluated on an in vitro model of human hepatocellular carcinoma (HepG-2 cells). Among all the tested algae, Asparagopsis armata, Fucus spiralis, Plocamium cartilagineum and Sphaerococcus coronopifolius presented the highest potential in both cytotoxicity and anti-proliferative studies. The activity evidenced by these four algae can be associated with the presence of sulfated polysaccharides, since in recent years these molecules have been reported with anti-proliferative activity on in vitro cancer models (cancer cellular lines), as well as inhibitive activity in tumours growing in mice. In addition, they have anti-metastatic activity blocking the interactions between cancer cells and the basement membrane (Costa et al. 2010; Rocha et al. 2005). Sulphated polysaccharides are found in varying amounts in three major divisions of marine algae, Rhodophyta (red algae), Heterokontophyta (brown algae) and Chlorophyta (green algae) (Wijesekara et al. 2011). The activity exhibited by brown algae, namely by Fucus spiralis can be related with the presence of fucoidans, which are sulfated polysaccharides produced only by brown algae. These molecules have been isolated from different species belonging to Fucus genus and have showed capacity to inhibit the growth, the angiogenesis and the invasion progressions of tumor cells (Ale et al. 2011; Hyun et al. 2009; Imbs et al. 2009; Kamihira et al. 2010; Skriptsova et al. 2012; Ye et al. 2005). Other group of sulphated polysaccharides, the heterofucans, were isolated and showed strong antiproliferative activity against HeLa cells and moderate activity on HepG-2 cells (Costa et al. 2011). A similar effect was observed with diterpenes isolated from the brown algae Dictoyota dichotoma, which exhibited a potent cytotoxicity on HepG-2 cells (Ayyad et al. 2011). Actually, terpenoids and polysaccharides are strong candidates to mediate the cytotoxic effect associated with alga Fucus spiralis. This fact is reinforced since these molecules can be extracted with methanol (polar), precisely the extract that revealed the highest activity in this study.

Red algae also showed interesting results on HepG-2 cells. Among these, A. armata, P. cartilagineum and S. coronopifolius had the highest effects on HepG-2 cells. Several studies have reported the antimicrobial activity of $A$. armata against different types of microorganisms, showing that this alga produce compounds with pharmacological potential (Genovese et al. 2009; Paul et al. 2006; Zbakh et al. 2012); however the cytotoxicity effects of this algae in cells lines were only reported by Zubia et al. (2009). On the other hand, the activity demonstrated by $P$. cartilagineum may be due to the presence of halogenated monoterpenes, since these molecules were already isolated from this alga and revealed high activity on SW480 cells (Inés et al. 2004). Nevertheless, the best activity in both studies was exhibited by the dichloromethane extract of S. coronopifolius that exhibited the lowest $\mathrm{IC}_{50}$ on cell viability and cell proliferation studies. These potential 
is not surprising since previous studies isolated diterpenes with great interest from $S$. coronopifolius collected in Mediterranean Sea (Piazza et al. 2011; Smyrniotopoulos et al. 2009). These molecules showed interesting results against several cells lines and were able to overcome the natural resistance of certain tumour cells to apoptosis (Smyrniotopoulos et al. 2008, 2010).

The potential of S. coronopifolius gets even more interesting when compared with the standard drugs, cisplatin and tamoxifen. In the anti-proliferative tests, the $\mathrm{IC}_{50}$ exhibited by the $S$. coronopifolius dichloromethane extract was similar to the $\mathrm{IC}_{50}$ exhibited by these antitumor drugs. By other side, in the cytotoxicity test, the dichloromethane extract of $S$. coronopifolius displayed an $\mathrm{IC}_{50}$ smaller than those drugs.

On the other hand, the environmental conditions to which algae are subjected can result in the production of different molecules, and the possibility of the presence of new molecules involved in the cytotoxicity and anti-proliferative effects presented in this work must be considered. Moreover, several authors have associated the production of compounds with toxicity and anti-proliferative activities to temporal-space variations, depending on the community or the season, pointing to the important role of biotic and abiotic factors (Marti et al. 2004; Osman et al. 2010; Taskin et al. 2010). These factors can also explain the absence of positive results of the algae belonging to Chlorophyta division. These did not show any potent activity on HepG-2 cells; however, previous studies reported anti-proliferative activity for green algae (Chlorophyta) on different cells lines (Costa et al. 2010; Kim et al. 2013; Villarreal-Gómez et al. 2010).

These results indicate the possible presence of compounds with huge potency. Moreover, the extracts here tested are a complex mixture of compounds and the portion of active compounds may be very low. These data support the view that $S$. coronopifolius can be an interesting source of molecules with antitumor potential.

\section{Conclusions}

In summary, the screening of this study allowed to select four algae from twelve with interesting antitumor potential on HepG-2 cells, namely Fucus spiralis, Asparagopsis armata, Plocamium cartilagineum and Sphaerococcus coronopifolius, being the highest activity exhibited by $S$. coronopifolius. Although this algae can be a promising source of new molecules with antitumor activity on hepatocellular carcinoma, this study is one of many steps required in order to obtain a therapeutic molecule. Further on it will be required to isolate, identify and purify the molecules with antitumor potential and also evaluate the intracellular signal pathways linked to the cell death mechanism or/and to the cell cycle regulation. Nevertheless, for our knowledge, this is the first antitumor screening on algae from the Peniche coast revealing high antitumor potential that opens a new opportunity window for cancer therapeutics research.

Authors' contributions

CA, SP and AH have been involved in the cytotoxicity and anti-proliferative assays. RP designed and coordinated the cytotoxicity and anti-proliferative assays and conceived the study. The manuscript was written by CA, SP, AH and RP. All authors read and approved the final manuscript.

Acknowledgements

This study had the support of the Fundação para a Ciência e a Tecnologia (FCT) through Red2Discovery Project (PTDC/MAR-BIO/6149/2014), co-financed by COMPETE (POCI-01-0145-FEDER-016791), and Strategic Project UID/ MAR/04292/2013 granted to MARE and the support of the FP7 EU project'BAMMBO: Sustainable production of Biologically Active Molecules of Marine Based Origin' (FP7 n 265896/http// www.bammbo.eu). C.A. and S.P. are 
financial supported by a grant from FCT—Fundação para a Ciência e Tecnologia (SFRH/BD/97764/2013 and SFRH/ BD/96203/2013, respectively).

\section{Competing interests}

The authors declare that they have no competing interests.

Received: 31 March 2016 Accepted: 28 July 2016

Published online: 12 August 2016

\section{References}

Ale MT, Maruyama H, Tamauchi H et al (2011) Fucoidan from Sargassum sp. and Fucus vesiculosus reduces cell viability of lung carcinoma and melanoma cells in vitro and activates natural killer cells in mice in vivo. Int J Biol Macromol 49:331-336

Allsopp M, Page R, Johnston P, Santillo D (2009) State of the World's Oceans. Springer, Heidelberg

Ayesha Hira, Sultana V et al (2010) In vitro cytotoxicity of seaweeds from Karachi coast on brine shrimp. Pak J Bot 42(5):3555-3560

Ayyad S-EN, Makki MS, Al-kayal NS et al (2011) Cytotoxic and protective DNA damage of three new diterpenoids from the brown alga Dictoyota dichotoma. Eur J Med Chem 46:175-182

Chew YL, Lim YY, Omar M, Khoo KS (2008) Antioxidant activity of three edible seaweeds from two areas in South East Asia. LWT Food Sci Technol 41:1067-1072

Chin Y-W, Balunas M, Chai H, Kinghorn AD (2006) Drug discovery from natural sources. AAPS J 8(2):E239-E253

Costa LS, Fidelis GP, Cordeiro SL et al (2010) Biological activities of sulfated polysaccharides from tropical seaweeds. Biomed Pharmacother 64:21-28

Costa LS, Fidelis GP, Telles CBS et al (2011) Antioxidant and antiproliferative activities of heterofucans from the seaweed Sargassum filipendula. Mar Drugs 9:952-966

Ebada SS, Lin W, Proksch P (2010) Bioactive sesterterpenes and triterpenes from marine sponges: occurrence and pharmacological significance. Mar Drugs 8:313-346

Fukahori S, Yano H, Akiba J et al (2008) Fucoidan, a major component of brown seaweed, prohibits the growth of human cancer cell lines in vitro. Mol Med Rep 1:537-542

Genovese G, Tedone L, Hamann M, Morabito M (2009) The Mediterranean red alga Asparagopsis: a source of compounds against Leishmania. Mar Drugs 7:361-366

Haefner B (2003) Drugs from the deep: marine natural products as drug candidates. Drug Discov Today 8:536-544

Hyun J-H, Kim S-C, Kang J-l et al (2009) Apoptosis inducing activity of fucoidan in HCT-15 colon carcinoma cells. Biol Pharm Bull 32:1760-1764

Imbs TI, Krasovskaya NP, Ermakova SP et al (2009) Comparative study of chemical composition and antitumor activity of aqueous-ethanol extracts of brown algae Laminaria cichorioides, Costaria costata, and Fucus evanescens. Russ J Mar Biol 35:164-170

Inés C, Argandoña VH, Rovirosa J et al (2004) Cytotoxic activity of halogenated monoterpenes from Plocamium cartilagineum. Z Naturforch 59:339-344

Jha R, Zi-rong X (2004) Biomedical compounds from marine organisms. Mar Drugs 2:123-146

Jimeno J, Faircloth G, Sousa-Faro J et al (2004) New marine derived anticancer therapeutics - a journey from the sea to clinical trials. Mar Drugs 2:14-29

Kamihira M, Katakura Y, Ito A (2010) Animal cell technology: basic \& applied aspects. Springer, Heidelberg

Kijjoa A, Sawangwong P (2004) Drugs and cosmetics from the sea. Mar Drugs 2:73-82

Kim A, Lee Y, Kang S-H et al (2013) Cytotoxic effect of clerosterol isolated from Codium fragile on A2058 human melanoma cells. Mar Drugs 11:418-430

Kuo Y-H, Liang T-W, Liu K-C et al (2011) Isolation and identification of a novel antioxidant with antitumour activity from Serratia ureilytica using squid pen as fermentation substrate. Mar Biotechnol 13:451-461

Kwon H-J, Bae S-Y, Kim K-H et al (2007) Induction of apoptosis in HeLa cells by ethanolic extract of Corallina pilulifera. Food Chem 104:196-201

Li Y-X, Wu H-X, Xu Y et al (2013) Antifouling activity of secondary metabolites isolated from chinese marine organisms. Mar Biotechnol 15:552-558

Lins KOAL, Bezerra DP, Alves APNN et al (2009) Antitumor properties of a sulfated polysaccharide from the red seaweed Champia feldmannii (Diaz-Pifferer). J Appl Toxicol 29:20-26

Marti R, Uriz MJ, Turon X (2004) Seasonal and spatial variation of species toxicity in Mediterranean seaweed communities: correlation to biotic and abiotic factors. Mar Ecol Prog Ser 282:73-85

Mayer AMS, Rodríguez AD, Berlinck RGS, Hamann MT (2009) Marine pharmacology in 2005-6: marine compounds with anthelmintic, antibacterial, anticoagulant, antifungal, anti-inflammatory, antimalarial, antiprotozoal, antituberculosis, and antiviral activities; affecting the cardiovascular, immune and nervous systems, and other miscellaneous mechanisms of action. Biochim Biophys Acta 1790:283-308

Murray PM, Moane S, Collins C et al (2013) Sustainable production of biologically active molecules of marine based origin. New Biotechnol 30:839-850

Osman MEH, Abushady AM, Elshobary ME (2010) In vitro screening of antimicrobial activity of extracts of some macroalgae collected from abu-Qir bay Alexandria. Afr J Biotechnol 9(12):7203-7208

Paul NA, Nys Rd, Steinberg PD (2006) Chemical defence against bacteria in the red alga Asparagopsis armata: linking structure with function. Mar Ecol Prog Ser 306:87-101

Pedrosa R, Soares-da-Silva P (2002) Oxidative and non-oxidative mechanisms of neuronal cell death and apoptosis by L-3,4-dihydroxyphenylalanine (L-DOPA) and dopamine. Br J Pharmacol 137:1305-1313 
Pereira L, Neto JM (2014) Marine algae: biodiversity, taxonomy, environmental assessment, and biotechnology. CRC Press, New York

Piazza V, Roussis V, Garaventa F et al (2011) Terpenes from the red alga Sphaerococcus coronopifolius inhibit the settlement of barnacles. Mar Biotechnol 13:764-772

Pinteus S, Alves C, Monteiro H et al (2015) Asparagopsis armata and Sphaerococcus coronopifolius as a natural source of antimicrobial compounds. World J Microbiol Biotechnol 31:445-451

Rocha HAO, Franco CRC, Trindade ES et al (2005) Fucan inhibits Chinese hamster ovary cell (CHO) adhesion to fibronectin by binding to the extracellular matrix. Planta Med 71:628-633

Salvador N, Garreta AG, Lavelli L, Ribera MA (2007) Antimicrobial activity of Iberian macroalgae. Sci Mar 71 (1):101-113

Shanmughapriya S, Manilal A, Sujith S et al (2008) Antimicrobial activity of seaweeds extracts against multiresistant pathogens. Ann Microbiol 58:535-541

Sithranga Boopathy N, Kathiresan K (2010) Anticancer drugs from marine flora: an overview. J Oncol 2010:1-18

Skriptsova A, Shevchenko N, Tarbeeva D, Zvyagintseva T (2012) Comparative study of polysaccharides from reproductive and sterile tissues of five brown seaweeds. Mar Biotechnol 14:304-311

Smyrniotopoulos V, Quesada A, Vagias C et al (2008) Cytotoxic bromoditerpenes from the red alga Sphaerococcus coronopifolius. Tetrahedron 64:5184-5190

Smyrniotopoulos V, Vagias C, Roussis V (2009) Sphaeroane and neodolabellane diterpenes from the red alga Sphaerococcus coronopifolius. Mar Drugs 7:184-195

Smyrniotopoulos V, Vagias C, Bruyère C et al (2010) Structure and in vitro antitumor activity evaluation of brominated diterpenes from the red alga Sphaerococcus coronopifolius. Bioorg Med Chem 18:1321-1330

Stonik VA (2009) Marine natural products: a way to new drugs. Acta Nat 2:15-25

Taskin E, Caki Z, Ozturk M, Taskin E (2010) Assessment of in vitro antitumoral and antimicrobial activities of marine algae harvested from the eastern Mediterranean Sea. Afr J Biotechnol 9(27):4272-4277

Thoppil RJ, Bishayee A (2011) Terpenoids as potential chemopreventive and therapeutic agents in liver cancer. World J Hepatol 3(9):228-249

Villarreal-Gómez $\sqcup$, Soria-Mercado IE, Guerra-Rivas G, Ayala-Sánchez NE (2010) Antibacterial and anticancer activity of seaweeds and bacteria associated with their surface. Rev Biol Mar Oceanogr 45(2):267-275

Wijesekara I, Pangestuti R, Kim S-K (2011) Biological activities and potential health benefits of sulfated polysaccharides derived from marine algae. Carbohydr Polym 84:14-21

Ye J, Li Y, Teruya K et al (2005) Enzyme-digested fucoidan extracts derived from seaweed Mozuku of Cladosiphon novaecaledoniae kylin inhibit invasion and angiogenesis of tumor cells. Cytotechnology 47:117-126

Ye H, Wang K, Zhou C et al (2008) Purification, antitumor and antioxidant activities in vitro of polysaccharides from the brown seaweed Sargassum pallidum. Food Chem 111:428-432

Yuan YV, Walsh NA (2006) Antioxidant and antiproliferative activities of extracts from a variety of edible seaweeds. Food Chem Toxicol 44:1144-1150

Zandi K, Ahmadzadeh S, Tajbakhsh S et al (2010) Anticancer activity of Sargassum oligocystum water extract against human cancer cell lines. Eur Rev Med Pharmacol Sci 14:669-673

Zbakh H, Chiheb H, Bouziane $\mathrm{H}$ et al (2012) Antibacterial activity of benthic marine algae extracts from the mediterranean coast of Morocco. J Microbiol Biotechnol Food Sci 2(1):219-228

Zubia M, Fabre M-S, Kerjean V, Deslandes E (2009) Antioxidant and cytotoxic activities of some red algae (Rhodophyta) from Brittany coasts (France). Bot Mar 52:268-277

\section{Submit your manuscript to a SpringerOpen ${ }^{\circ}$ journal and benefit from:}

- Convenient online submission

$\checkmark$ Rigorous peer review

- Immediate publication on acceptance

- Open access: articles freely available online

- High visibility within the field

- Retaining the copyright to your article

Submit your next manuscript at $\boldsymbol{\nabla}$ springeropen.com 